\title{
Aspen Plus Simulation Strategies Applied to the Study of Chitin Bioextraction from Shrimp Waste
}

\section{David Gómez-Ríos ${ }^{1 *}$ (0), Grace Navarro' ${ }^{\circledR}$, Paola Monsalve ${ }^{1}$, Rolando Barrera-Zapata ${ }^{2}$ and Rigoberto Ríos-Estepa² ${ }^{2}$}

${ }^{1}$ Group of Bioprocesses, Chemical Engineering Department, Engineering Faculty, University of Antioquia (UdeA) Calle 70 No. 52-21, Medellín 050010, Colombia

${ }^{2}$ Group CERES, Chemical Engineering Department, Engineering Faculty, University of Antioquia (UdeA), Calle 70 No. 52-21, Medellín 050010, Colombia

Received: 22 August 2018 Accepted: 2 May 2019
*Corresponding author: Phone: +573188348832

E-mail: dandres.gomez@udea.edu.co

\begin{abstract}
SUMMARY
Chitin is an aminopolysaccharide of industrial interest commonly obtained from shrimp processing waste through chemical or biotechnological means. Current environmental concerns offer a stimulating perspective for chitin bioextraction with lactic acid bacteria since a considerable reduction in the use of corrosive and pollutant products is possible. Nevertheless, the efficiency of this bioprocess is still a matter of discussion. In this work, the experimental studies of chitin bioextraction from Pacific white shrimp (Litopenaeus vannamei) waste with a mixed culture of Lactobacillus plantarum, Lactobacillus bulgaricus and Streptococcus thermophilus are used in process simulation using Aspen Plus software for the analysis of the potential application of a bioprocess on plant scale. The experimental results of characterization in shake flasks and 1-litre bioreactor indicated that $50 \mathrm{~h}$ of fermentation with the mixed culture of lactic acid bacteria was enough to extract more than $90 \%$ of minerals and proteins from the shrimp waste. The use of experimental parameters in the simulation allowed a reliable representation of the bioprocess yielding normalized root mean square values below $10 \%$. Simulation was used for the assessment of the impact of the raw material variability on the production costs and gross margin. In this regard, the gross margin of the operation ranged from 42 to $52 \%$ depending on the raw material composition and product yield.
\end{abstract}

Key words: Aspen Plus, chitin, bioextraction, bioprocess simulation, lactic acid bacteria

\section{INTRODUCTION}

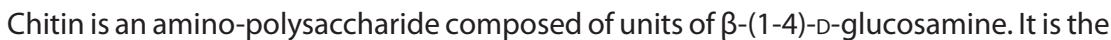
second most abundant polysaccharide in nature after cellulose, appearing in the structure of arthropods, fungi and algae (1). It exhibits antibacterial, antifungal and chelating properties; it is often used in the manufacture of sponges and dressings for the treatment of wounds and burns, in water treatment as chelating agent and in agriculture to protect plants and crops (2). Due to the extensive processing of seafood products, the generation of waste derived from the industrial processing of shrimps has increased significantly and become an environmental problem $(3,4)$. However, in the last years the use of shrimp and other shellfish debris to produce chitin and chitosan has emerged as an environmental and economic alternative to the final disposal of this waste (5).

Chitin is mostly produced by chemical extraction of seafood waste (6). Such chemical process involves a depigmentation stage with an organic solvent, followed by deproteinization with alkaline solutions and demineralization with diluted acid $(4,7)$. Alternatively, seafood waste can be bioprocessed using bacteria, fungi or enzymes for partial or complete extraction of pigments, fat, minerals and proteins, avoiding the intensive use of aggressive and chemical pollutants $(4,8)$.

The integration of simulation tools in process development allows the analysis of different aspects of the process feasibility. Such computational approach can contribute to the identification and overcoming of some of the process handicaps prior to scale-up and design (9). Process simulation is often used to analyse the economic feasibility of processing 
scenarios, process performance and optimization, and parameter estimation; therefore, it facilitates equipment design, sizing and cost evaluation (9-11). Nevertheless, in the field of bioprocessing, process simulation with commercial software is a challenging task and it requires the implementation of alternative strategies to represent the chemical species and reactions involved in microbial metabolism (12). Additionally, typical commercial process simulators do not include the basic equipment used in bioprocessing; besides, literature regarding computer-aided simulation in bioprocesses and methodologies to overcome software limitations is still limited (12).

In this work, a combined approach of experimental studies and simulation in Aspen Plus v. 8.8 (13) is used to analyse the process of chitin bioextraction with lactic acid bacteria. Aspen Plus is considered a versatile simulation software used to improve the performance and design of chemical plants. Despite the remarkable advantages of this software for the representation of petrochemical and chemical processes, its features are limited for simulation of bioprocesses. The aim of this contribution is to present a complete description of the experiment-based simulation approach implemented in Aspen Plus for the technical and cost analyses of chitin bioextraction from shrimp waste.

\section{MATERIALS AND METHODS}

\section{Material characterization}

Pretreated and milled Pacific white shrimp (Litopenaeus vannamei) waste was supplied by a local shrimp processing plant from Medellín, Colombia (609'54.7"N 75³6'31.9"W). The samples of shrimp waste with particle size between 0.9 and $1.5 \mathrm{~mm}$ were characterized and used as raw material for bioprocessing with lactic acid bacteria $(\mathrm{LAB})(7,8)$. The ash content of the samples was quantified by mass difference before and after calcination in a furnace (ES 267; Industrias Terrígeno S.A., Medellín, Colombia) at $450-575{ }^{\circ} \mathrm{C}$ during 3-4 h. Additionally, calcium, magnesium, sodium and potassium were determined by flame atomic absorption spectrophotometry (Avanta S; GBC Scientific Equipment, Melbourne, Australia) according to Rødde et al. (14). Astaxanthin was extracted with absolute ethanol (Carlo Erba, Chaussée du Vexin, France) in a solid to liquid ratio 1:5, at room temperature for $35 \mathrm{~min}$ and then quantified with a spectrophotometer (Spectronic Helios Alpha; Thermo Fisher Scientific, Waltham, MA, USA) at $476 \mathrm{~nm}$ (14). Deproteinization was carried out with $0.9 \mathrm{M}$ sodium hydroxide (Carlo Erba) in a solid to liquid ratio $1: 24$ for $3.4 \mathrm{~h}$ at $70^{\circ} \mathrm{C}$. Demineralization was performed using 1.5 M hydrochloric acid (J.T.Baker, Avantor, Radnor, PA, USA) in a solid to liquid ratio 1:10 for $70 \mathrm{~min}$ at room temperature. In all the extraction stages, constant stirring at $700 \mathrm{rpm}$ occurred on a stirring hotplate (PC420D; Corning Inc, Lowell, MA, USA). The percentage of total nitrogen $\left(\mathrm{N}_{\mathrm{T}}\right)$ in the crude and treated samples was also determined by the Kjeldahl method (15) as follows: samples of $1 \mathrm{~g}$ were digested with $20 \mathrm{~mL}$ of concentrated sulfuric acid (J.T.Baker, Avantor) containing two
Kjeldahl copper catalyst tablets (Panreac Applichem, Darmstadt, Germany) at $420^{\circ} \mathrm{C}$ for $2 \mathrm{~h}$, followed by cooling, neutralization with sodium hydroxide (50\%) (Carlo Erba) and titration with hydrochloric acid (0.25 M) (J.T.Baker, Avantor) in a Kjeldahl equipment (Bioasiel Laboratorios S.A.S., Medellín, Colombia). The $\mathrm{N}_{\mathrm{T}}$ measured in the crude samples included nitrogen present in proteins and chitin, while in the treated samples, it corresponded only to nitrogen present in the units of $\mathrm{N}$-acetylglucosamine. Thus, the $\mathrm{N}_{\mathrm{T}}$ was used for calculation of chitin and protein contents in the samples according to Eqs. 1, 2 and 3 (16):

$$
w(\mathrm{NNC})=w(\mathrm{M})+w(\mathrm{~L})+w\left(\mathrm{H}_{2} \mathrm{O}\right)
$$

where $w(\mathrm{NNC})$ is the mass fraction in \% of all non-nitrogen compounds, i.e. the sum of mass fractions of minerals (M), lipids (L) and water in the samples. Chitin and protein contents were calculated according to the following equations:

$$
w(\mathrm{Q})=\frac{\left(w\left(\mathrm{~N}_{\mathrm{T}}\right) \cdot \mathrm{cf}_{\mathrm{p}}+w(\mathrm{NNC})-100\right) \cdot \mathrm{cf}_{\mathrm{q}}}{\mathrm{cf}_{\mathrm{p}}-\mathrm{cf}_{\mathrm{q}}}
$$

and

$$
w(\mathrm{P})=\frac{\left(w\left(\mathrm{~N}_{\mathrm{T}}\right) \cdot \mathrm{cf}_{\mathrm{q}}+w(\mathrm{NNC})-100\right) \cdot \mathrm{cf}_{\mathrm{p}}}{\mathrm{cf}_{\mathrm{q}}-\mathrm{cf}_{\mathrm{p}}}
$$

where $w(\mathrm{Q})$ and $w(\mathrm{P})$ are the chitin and protein mass fractions and $\mathrm{cf}_{\mathrm{p}}$ and $\mathrm{cf}_{\mathrm{q}}$ are the conversion factors from total Kjeldahl nitrogen to protein and chitin, respectively. The reported value of $\mathrm{cf}_{\mathrm{p}}$ is 6.25 and of $\mathrm{cf}_{\mathrm{q}}$ is 14.5 (16). Additionally, protein was also quantified in the supernatants by the Lowry method after chemical deproteinization of the samples (15). Moreover, extraction with ether (J.T.Baker, Avantor) was carried out in a Soxhlet apparatus (Bioasiel Laboratorios S.A.S.) for lipid fraction quantification (14).

\section{Fermentation of shrimp processing waste}

Separated cultures of native species of Lactobacillus plantarum, Lactobacillus bulgaricus and Streptococcus thermophilus were used for the preparation of the inoculum and the shrimp fermentation in the bioreactor. The native LAB were kindly provided by the Research Group of Biotransformation and Research Group in Nutrition and Food Technology of the University of Antioquia (Medellín, Colombia). The activation of the strains was done in De Man, Rogosa and Sharpe (MRS) agar (Merck, Darmstadt, Germany). Mixed liquid inoculum was prepared by inoculating $1.1 \cdot 10^{6} \mathrm{CFU} / \mathrm{mL}$ of each strain in the MRS liquid medium (Merck) at $\mathrm{pH}=6.4$ and then it was incubated for $48 \mathrm{~h}$ at $140 \mathrm{rpm}$ and $30^{\circ} \mathrm{C}$ in a benchtop shaker (Lab companion SI-300; GMI, Ramsey, MN, USA) under anaerobic conditions.

A design of experiments (DOE) of surface response type (2-squared plus 2-star points) with duplicates was performed for optimization of culture conditions. The DOE takes into account the temperature, carbon source concentration in the medium and solid to liquid ratio of solid waste for achieving 
the highest mineral and protein extraction. The DOE and statistical analyses for $95 \%$ confidence were performed in Statgraphics Centurion XVII (17).

Samples of $4.2 \mathrm{~g}$ of pretreated shrimp waste were used for the fermentation experiments in shake flasks at $178 \mathrm{rpm}$ for $48 \mathrm{~h}$. Lactate in the supernatant was determined as titratable acidity (TTA) by potentiometric titration with $0.1 \mathrm{M} \mathrm{NaOH}$ (18) and glucose was quantified by the dinitrosalicylic acid method at $575 \mathrm{~nm}$ (19). After fermentation, the solids were filtered, dried and deproteinized chemically; the liquid fraction was then analysed with the Lowry method (15) for determination of the remaining proteins. The deproteinization (\%) was calculated by the difference between the initial and final protein content in the samples according to Eq. 4 (20):

$$
\text { Deproteinization }=\left(\frac{w\left(\mathrm{P}_{\mathrm{c}}\right) \cdot m_{\mathrm{c}}-w\left(\mathrm{P}_{\mathrm{F}}\right) \cdot m_{\mathrm{F}}}{w\left(\mathrm{P}_{\mathrm{c}}\right) \cdot m_{\mathrm{c}}}\right) \cdot 100
$$

where $w\left(\mathrm{P}_{c}\right)$ and $w\left(\mathrm{P}_{\mathrm{f}}\right)$ are the protein mass fractions (\%) in and $m_{\mathrm{c}}$ and $m_{\mathrm{f}}$ are the masses ( $\mathrm{g}$ ) of crude and fermented samples, respectively.

Similarly, ash content was determined by calcinating the deproteinized solids and the demineralization (\%) was determined from the difference in the ash content before and after the fermentation according to Eq. 5 (20):

$$
\text { Demineralization }=\left(\frac{w\left(\mathrm{M}_{\mathrm{c}}\right) \cdot m_{\mathrm{c}}-w\left(\mathrm{M}_{\mathrm{F}}\right) \cdot m_{\mathrm{F}}}{w\left(\mathrm{M}_{\mathrm{c}}\right) \cdot m_{\mathrm{c}}}\right) \cdot 100
$$

where $w\left(\mathrm{M}_{\mathrm{c}}\right)$ and $w\left(\mathrm{M}_{\mathrm{f}}\right)$ are the mineral mass fractions (\%) in crude and fermented samples, respectively.

An additional set of experiments was performed to determine the kinetic parameters of demineralization and deproteinization at 37,40 and $43^{\circ} \mathrm{C}$. Crude and deproteinized samples of shrimp waste were treated separately with lactic acid (10.3\% by mass). Supernatant was withdrawn at intervals of $10 \mathrm{~h}$ for TTA determination and astaxanthin quantification. Since demineralization is caused by the reaction of carbonates and phosphates with lactic acid, the time course of the lactic acid molar concentration was used to calculate the reaction rates at the given temperatures. The lactic acid consumed during deproteinization was calculated by the difference in the acid requirement for complete removal of proteins in crude and fermented samples. Additionally, for the kinetic calculations, the time courses of biomass growth and pigment dissolution were followed during fermentation in shake flasks at $40^{\circ} \mathrm{C}$. Semi-log plots of concentration data were used for the calculation of the Arrhenius kinetic parameters by linear regression using the least squares method.

The optimal statistical point of operation was identified and then used for validation on the bioreactor scale. Batch fermentations of shrimp waste were done in duplicate in 1-litre stirred tank bioreactor (BIOSTAT ${ }^{\circledR}$ A, Sartorius, Göttingen, Germany) under the previously determined optimal operating conditions. The bioreactor was inoculated with 10 $\%$ (by volume) starter culture and operated at $500 \mathrm{rpm}$ with filling volume of $0.7 \mathrm{~L}$, with an initial $\mathrm{pH}=6.4$. The fermentation medium contained the following (in $\mathrm{g} / \mathrm{L}$ ): magnesium sulphate 0.2 , manganese sulphate 0.05 , sodium acetate 5 , dipotassium hydrogen phosphate 2 , and glucose $10.3 \%$ (by mass) (all from Merck). Fermentations were monitored during 4 days by sampling at regular intervals of $10 \mathrm{~h}$ for biomass, lactate, glucose, mineral, pigment and protein quantifications as previously described.

\section{Simulation strategy}

Fig. 1 summarizes the workflow followed in the simulation of plant process using the sequential modular approach in Aspen Plus v. 8.8 (13). In this approach, the global results are reached after solving the individual models of the equipment following a specific calculation order; thus, the numerical results of the first model are used in the second and so on, until the global results are obtained.

Aspen Plus solver implements hypothetical holding tanks to reach the steady state solution of plant models consisting of continuous and non-continuous equipment. Nevertheless, an under- or overestimation of mass and energy balance might occur due to the assumption of continuous flow to the holding tanks.

The bioprocess of chitin extraction was simulated as a combination of three independent units where the composition of the feed streams was defined according to the simulation results of the previous stage. Hence, the in-flow was calculated based on the cycle time defined for each unit. The simulation flowsheet of the process is presented in Fig. 2.

\section{Component definition}

Since the raw material used in the process is a natural product, the definition of MATERIAL stream (Fig. 2a) required the specification of some user-defined compounds and the rest of them were directly retrieved from the Aspen databank. The component definition is a critical step in the simulation setup, because the components must have physical and chemical properties that allow the approximation of the real materials used in the process $(10,21)$.

The MATERIAL stream (Fig. 2a) was specified as a conventional solid stream with a defined particle size diameter (CIPSD) (data not shown) according to the experimental composition given in Table 1, assuming the processing of $248 \mathrm{~kg}$ of dried shrimp waste per batch. The mineral components, i.e. calcium, sodium and magnesium carbonate and calcium phosphate, were directly defined as conventional compounds, since they were available in the Aspen databank. On the other hand, the proteins were simulated as dipeptides formed by five representative amino acids: methionine, phenylalanine, alanine, glutamic acid and lysine, which were selected under structural criteria of composition according to the experimental characterization reported in the literature (22). These dipeptides 


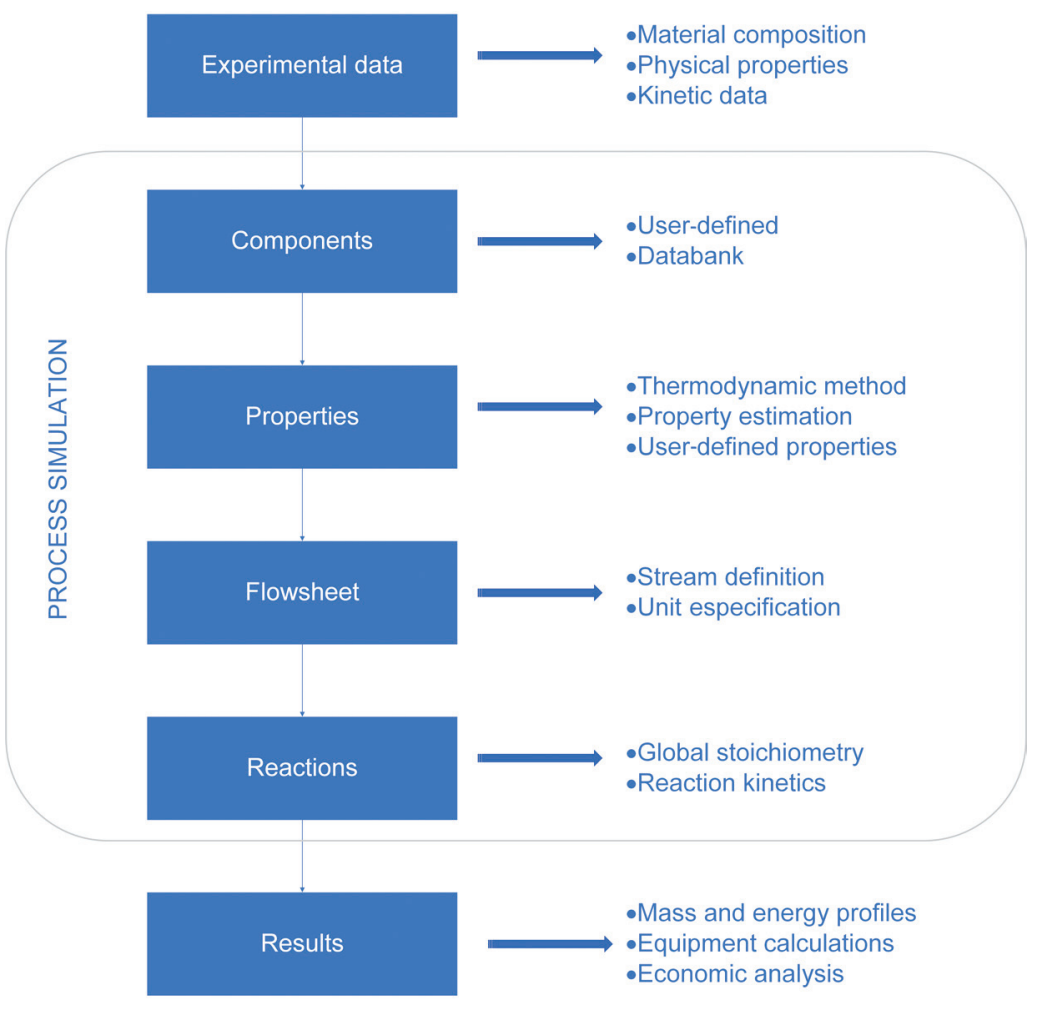

Fig. 1. Simulation strategy workflow

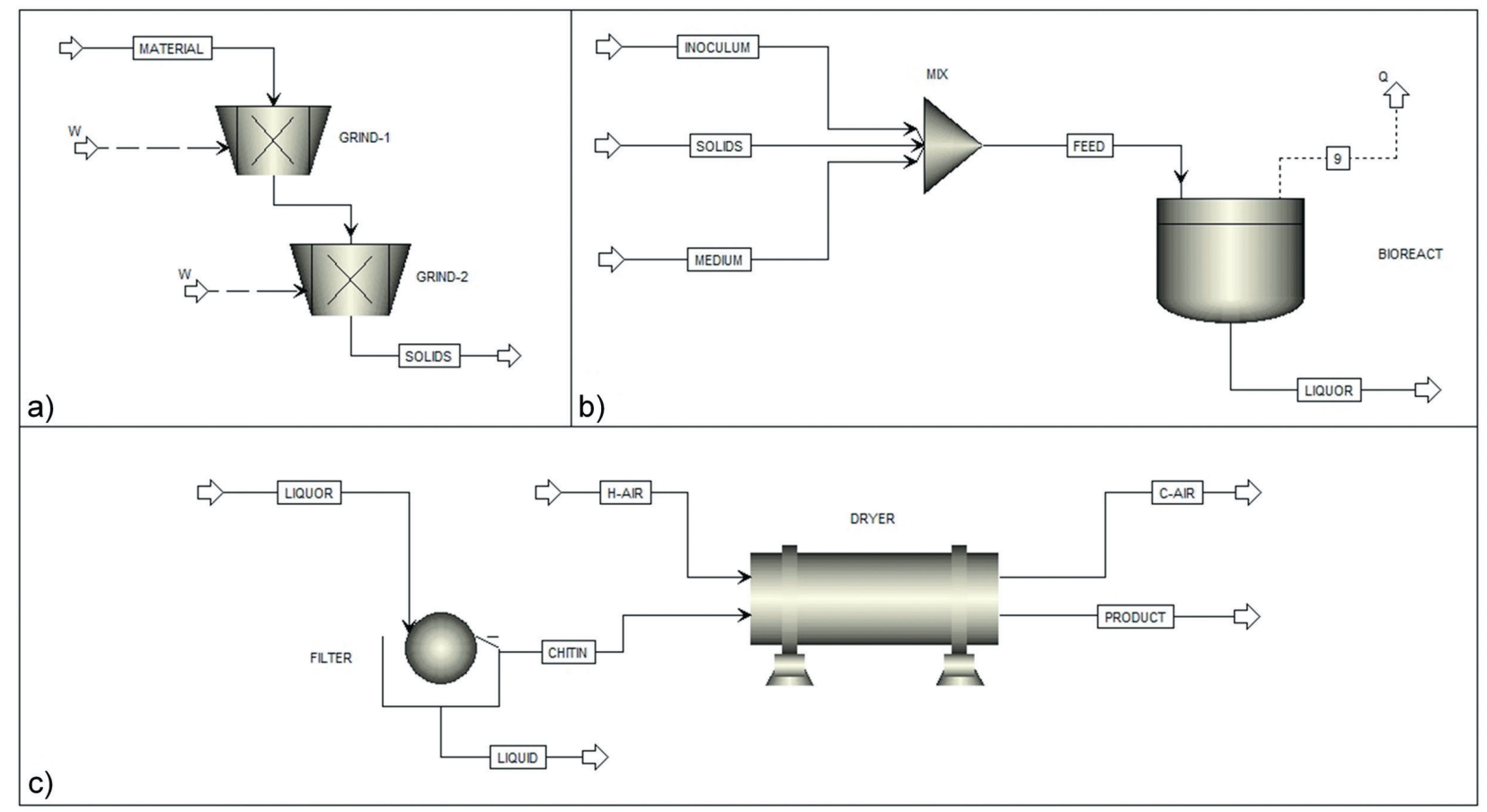

Fig. 2. Aspen Plus (13) flowsheet for the simulation of the fermentative production of chitin: a) size reduction, b) bioreactor, and c) filtration and drying

must be user-defined compounds and their chemical structures were entered into the software. Chitin was assumed as its constitutive unit ( $\mathrm{N}$-acetyl-D-glucosamine), fat content was represented by the fatty ester methyl palmitate and astaxanthin was selected as the pigment component; all these compounds were added to the software databank. 
Table 1. Mean composition of dried shrimp waste (248 kg per batch) and calculated feed used for the process simulation

\begin{tabular}{lcc} 
Component & $w / \%$ & $m(\mathrm{feed}) / \mathrm{kg}$ \\
Protein & $38.40 \pm 0.10$ & 95.1 \\
Chitin & $31.40 \pm 0.10$ & 77.9 \\
Calcium phosphate & $13.50 \pm 0.02$ & 33.5 \\
Fat & $6.70 \pm 0.12$ & 16.7 \\
Calcium carbonate & $5.40 \pm 0.02$ & 13.3 \\
Sodium carbonate & $2.70 \pm 0.02$ & 6.8 \\
Magnesium carbonate & $1.60 \pm 0.02$ & 3.9 \\
Astaxanthin & $0.400 \pm 0.002$ & 1.1 \\
\hline
\end{tabular}

The streams other than MATERIAL were defined as a substream carrying the conventional non-solid elements (MIXED substream) and a substream carrying the solids with a specified particle size diameter (CIPSD substream). The fermentation medium was assumed to consist only of dextrose $(10.3 \%$ by mass) as carbon source and water; both substances included in the software database. Other components of the medium, e.g. salts and trace elements, were neglected due to the simplifications used in the reactions proposed to represent the bacterial growth. It was considered that LAB metabolism produced biomass and lactic acid as the main products. The lactic acid was available in Aspen databank and the biomass was a user-defined compound based on the elemental composition reported in the literature for $\operatorname{LAB}(23,24)$. The conventional and the user-defined components used in the simulation are given in Table S1.

The Electrolyte Non-Random Two-Liquid-Redlich-Kwong (ENRTL-RK) thermodynamic model was selected as the property estimation method, since this model is suitable for modelling aqueous solutions of salts and organic weak electrolytes. The physical properties of the conventional components were calculated by the software from property models associated with the thermodynamic model. In the case of the user-defined compounds, the molecular structure and the thermochemical data were provided. The solid heat capacities of the dipeptides and chitin were taken from the literature $(25,26)$, and the Gibbs free energy and the enthalpy of biomass formation were estimated from the experimental data reported in the literature $(24,27)$. Densities, molar volumes and other required data were taken from material data sheets and the NIST chemistry database (28).

\section{Simulation of size reduction}

The efficiency of the fermentative removal of minerals and proteins considerably depends on a good dispersion of the solids in the liquid medium, which can be achieved with particle sizes smaller than $2 \mathrm{~mm}$ (7). The size reduction requirements imply the use of primary and secondary size reduction units, GRIND-1 and GRIND-2 in Fig. 2a, respectively; which were simulated as cage mill crushers. This kind of crushers are highly recommended for size reduction operations of wet and sticky materials (29). Size reduction was simulated in the 'equipment selection' mode and the ratio of cut-off size to outlet diameter was fixed at 6.0. The maximum particle size defined was $1.7 \mathrm{~mm}(7,30)$ and the grindability of the material was characterized by a Bond work index of $49.6 \mathrm{~kJ} / \mathrm{kg}$.

\section{Bioreactor simulation}

The fermentation was simulated using the built-in batch reactor model (R-Batch) shown in Fig. 2b. The stream GRINDED (Figs. 2a and 2b) contained the raw material including chitin, proteins, minerals, fat and pigments; the stream INOCULUM (Fig. 2b) was composed of the initial biomass and the stream MEDIUM (Fig. 2b) was composed of dextrose and water. The streams FEED and LIQUOR (Fig. 2b) represented the charge and discharge of the reactor. The fermentation was simulated as a batch isothermal process at $40^{\circ} \mathrm{C}$ and $100 \mathrm{kPa}$ with a total cycle time of $150 \mathrm{~h}$. The $\mathrm{R}$-Batch model requires the specification of reaction kinetics and stoichiometry; in this case, a set of 13 reactions (Table 2 ) was defined to simulate the growth, lactic acid production, and demineralization, deproteinization and depigmentation processes using empirical kinetic parameters. In the demineralization and deproteinization reactions, the kinetic factor for each reaction $\left(k_{\mathrm{i}}\right)$ was calculated from the total kinetic factor $\left(k_{\mathrm{T}}\right)$ given in Table 3 and the total number of reactions, according to Eqs. 6 and 7 as follows:

$$
\frac{\mathrm{d} c_{\mathrm{A}}}{\mathrm{d}_{\mathrm{t}}}=-r_{\mathrm{A}}=-\sum_{\mathrm{i}=1}^{4} k_{\mathrm{i}} \cdot e^{-\mathrm{E}_{\mathrm{m}} / \mathrm{RT}} \cdot c_{\mathrm{A}}^{2}=-k_{\mathrm{T}} \cdot e^{-\mathrm{E}_{\mathrm{m}} / \mathrm{RT}} \cdot c_{\mathrm{A}}^{2}
$$

and

$$
k_{\mathrm{T}}=\sum_{\mathrm{i}=1}^{4} k_{\mathrm{i}}
$$

where $r_{A}$ is the reaction rate of lactic acid $\left(\mathrm{kmol} /\left(\mathrm{m}^{3} \cdot \mathrm{h}\right)\right), c_{\mathrm{A}}$ lactic acid concentration $\left(\mathrm{kmol} / \mathrm{m}^{3}\right), E_{m}$ molar activation energy of the reaction $(\mathrm{kJ} / \mathrm{kmol}), R$ molar gas constant $(\mathrm{kJ} /(\mathrm{K} \cdot \mathrm{kmol}))$ and $T$ thermodynamic temperature $(\mathrm{K})$.

Table 2. Reaction set defined for the simulation of fermentative production of chitin

Reaction stoichiometry
Depigmentation
$\mathrm{C}_{40} \mathrm{H}_{52} \mathrm{O}_{4(s)} \rightarrow \mathrm{C}_{40} \mathrm{H}_{52} \mathrm{O}_{4}$
Deproteinization
$\mathrm{C}_{6} \mathrm{H}_{12} \mathrm{~N}_{2} \mathrm{O}_{3}+\mathrm{C}_{3} \mathrm{H}_{6} \mathrm{O}_{3}+2 \mathrm{H}_{2} \mathrm{O} \rightarrow 2 \mathrm{C}_{3} \mathrm{H}_{7} \mathrm{NO}_{2}+\mathrm{C}_{3} \mathrm{H}_{5} \mathrm{O}_{3}{ }^{-}+\mathrm{H}_{3} \mathrm{O}^{+}$
$\mathrm{C}_{10} \mathrm{H}_{16} \mathrm{~N}_{2} \mathrm{O}_{7}+\mathrm{C}_{3} \mathrm{H}_{6} \mathrm{O}_{3}+2 \mathrm{H}_{2} \mathrm{O} \rightarrow 2 \mathrm{C}_{5} \mathrm{H}_{9} \mathrm{NO}_{4}+\mathrm{C}_{3} \mathrm{H}_{5} \mathrm{O}_{3}{ }^{-}+\mathrm{H}_{3} \mathrm{O}^{+}$
$\mathrm{C}_{18} \mathrm{H}_{20} \mathrm{~N}_{2} \mathrm{O}_{3}+\mathrm{C}_{3} \mathrm{H}_{6} \mathrm{O}_{3}+2 \mathrm{H}_{2} \mathrm{O} \rightarrow 2 \mathrm{C}_{9} \mathrm{H}_{11} \mathrm{NO}_{2}+\mathrm{C}_{3} \mathrm{H}_{5} \mathrm{O}_{3}^{-}+\mathrm{H}_{3} \mathrm{O}^{+}$
$\mathrm{C}_{10} \mathrm{H}_{20} \mathrm{~N}_{2} \mathrm{O}_{3} \mathrm{~S}_{2}+\mathrm{C}_{3} \mathrm{H}_{6} \mathrm{O}_{3}+2 \mathrm{H}_{2} \mathrm{O} \rightarrow 2 \mathrm{C}_{5} \mathrm{H}_{11} \mathrm{NO}_{2} \mathrm{~S}^{+} \mathrm{C}_{3} \mathrm{H}_{5} \mathrm{O}_{3}{ }^{-}+\mathrm{H}_{3} \mathrm{O}^{+}$
$\mathrm{C}_{12} \mathrm{H}_{26} \mathrm{~N}_{4} \mathrm{O}_{3}+\mathrm{C}_{3} \mathrm{H}_{6} \mathrm{O}_{3}+2 \mathrm{H}_{2} \mathrm{O} \rightarrow 2 \mathrm{C}_{6} \mathrm{H}_{14} \mathrm{~N}_{2} \mathrm{O}_{2}+\mathrm{C}_{3} \mathrm{H}_{5} \mathrm{O}_{3}{ }^{-}+\mathrm{H}_{3} \mathrm{O}^{+}$
Demineralization
$\mathrm{CaCO}_{3}+2 \mathrm{C}_{3} \mathrm{H}_{6} \mathrm{O}_{3}+2 \mathrm{H}_{2} \mathrm{O} \rightarrow \mathrm{Ca}^{2+}+2 \mathrm{C}_{3} \mathrm{H}_{5} \mathrm{O}_{3}{ }^{-}+3 \mathrm{H}_{2} \mathrm{O}+\mathrm{CO}_{2}$
$\mathrm{Na}_{2} \mathrm{CO}_{3}+2 \mathrm{C}_{3} \mathrm{H}_{6} \mathrm{O}_{3}+2 \mathrm{H}_{2} \mathrm{O} \rightarrow 2 \mathrm{Na}^{+}+2 \mathrm{C}_{3} \mathrm{H}_{5} \mathrm{O}_{3}^{-}+3 \mathrm{H}_{2} \mathrm{O}+\mathrm{CO}_{2}$
$\mathrm{MgCO}_{3}+2 \mathrm{C}_{3} \mathrm{H}_{6} \mathrm{O}_{3}+2 \mathrm{H}_{2} \mathrm{O} \rightarrow \mathrm{Mg}^{2+}+2 \mathrm{C}_{3} \mathrm{H}_{5} \mathrm{O}_{3}^{-}+3 \mathrm{H}_{2} \mathrm{O}+\mathrm{CO}_{2}$
$\mathrm{Ca}_{3}\left(\mathrm{PO}_{4}\right)_{2}+6 \mathrm{C}_{3} \mathrm{H}_{6} \mathrm{O}_{3} \rightarrow 3 \mathrm{Ca}^{2+}+6 \mathrm{C}_{3} \mathrm{H}_{5} \mathrm{O}_{3}{ }^{-}+2 \mathrm{H}_{3} \mathrm{PO}_{4}$
Biological
$\mathrm{C}_{3} \mathrm{H}_{7} \mathrm{NO}_{2}+\mathrm{H}_{2} \mathrm{O} \rightarrow \mathrm{C}_{3} \mathrm{H}_{6} \mathrm{O}_{3}+\mathrm{NH}_{3}$
$\mathrm{C}_{6} \mathrm{H}_{12} \mathrm{O}_{6} \rightarrow 2 \mathrm{C}_{3} \mathrm{H}_{6} \mathrm{O}_{3}$
$7 \mathrm{C}_{6} \mathrm{H}_{12} \mathrm{O}_{6}+8 \mathrm{NH}_{3} \rightarrow 4 \mathrm{C}_{10} \mathrm{H}_{18} \mathrm{O}_{5} \mathrm{~N}_{2}+18 \mathrm{H}_{2} \mathrm{O}+2 \mathrm{CO}_{2}$


Table 3. Arrhenius kinetic parameters for the bioextraction of chitin

\begin{tabular}{|c|c|c|c|c|}
\hline Process & $\mathrm{r} /\left(\mathrm{kmol} /\left(\mathrm{m}^{3} \cdot \mathrm{h}\right)\right)$ & $k_{\mathrm{T}}$ & $E_{m} /(\mathrm{kJ} / \mathrm{kmol})$ & $r^{2}$ \\
\hline Depigmentation & $k_{\mathrm{T}} \cdot c_{\text {pigment, }} .1 .61$ & 0.0067 & & 0.947 \\
\hline Deproteinization & $k_{\mathrm{T}} \cdot \mathrm{e}_{\mathrm{m}}^{-E} / R T \cdot c_{\text {lactate }}{ }^{2}$ & 2.64 & 11890 & 0.991 \\
\hline Demineralization & $k_{\mathrm{T}} \mathrm{e}_{\mathrm{m}}^{-E} \cdot{ }^{/ R T} \cdot c_{\text {lactate }}{ }^{2}$ & 22.69 & 23046 & 0.988 \\
\hline Biomass synthesis & $k_{\mathrm{T}} \mathrm{e}^{-E}{ }_{\mathrm{m}} / R T \cdot c_{\text {biomass }}$ & 0.345 & 43.4 & 0.837 \\
\hline Glucose consumption & $k_{\mathrm{T}} \mathrm{e}_{\mathrm{m}}^{-E} / R T \cdot c_{\text {glucose }} \cdot c_{\text {biomass }}$ & 0.492 & 2476.8 & 0.991 \\
\hline
\end{tabular}

$r=$ reaction rate, $c_{\mathrm{i}}=$ concentration $\left(\mathrm{kmol} / \mathrm{m}^{3}\right), k_{\mathrm{T}}=$ total kinetic factor, $E_{\mathrm{m}}=$ molar activation energy, $R=$ gas constant, $T=$ temperature $(\mathrm{K}), \mathrm{r}^{2}=$ regression correlation coefficient

Based on the experimental reaction kinetics, the mechanism of acid hydrolysis was assumed as prevalent in the deproteinization of the solids. In the case of demineralization, the solid salts react with the lactic acid producing calcium, magnesium and sodium lactates. Depigmentation was simulated as a chemical reaction in which the pigment in the solid substream dissolves into the liquid phase. An additional set of biological reactions represented the hydrolysis of alanine producing ammonium as nitrogen source, the lactic acid production and the biomass biosynthesis.

\section{Solid-liquid separation}

The filtration step (Fig. 2c) was simulated as standard rotary drum filters since this kind of filters are suitable for dewatering, washing and clarification operations. In the simulations, the following parameters were defined: maximum pressure drop of $40 \mathrm{kPa}$, width to diameter ratio of $2.0,0.25 \mathrm{rpm}, 120^{\circ}$ filtration angle, a filter medium resistance of $4.05 \cdot 10^{9} \mathrm{~m}^{-1}$, porosity of 0.4 , average sphericity of 0.5 and specific cake resistance of $2.0 \cdot 10^{6}$ $\mathrm{m} / \mathrm{kg}$ (31). In the simulation of the drying stage, a moisture of $19 \%$ (by mass) after filtration was assumed, air with $10 \%$ absolute humidity was selected as drying medium (32) and the load of solids was projected to be dried after $0.5 \mathrm{~h}$. The operation was specified at $140 \mathrm{kPa}$ with $20^{\circ} \mathrm{C}$ of superheating. Soave-Redlich-Kwong (SRK) equation of state and steam tables were used as property methods.

\section{RESULTS AND DISCUSSION}

\section{Bioextraction of chitin}

The experimental mean composition of shrimp waste and the calculated feed for simulation of the plant process are given in Table 1. The protein, mineral, chitin and pigment contents depend markedly on nutritional conditions; the results obtained in this study are in the range reported for this shrimp species (33). The astaxanthin content was slightly higher, possibly due to the supplementation of shrimp feed with carotenoids (34).

The optimal operating conditions according to the DOE were: isothermal operation at $40^{\circ} \mathrm{C}$, solid to liquid ratio $1: 10$ and carbon source mass fraction of $10.3 \%$ (Table S2). Notice that the optimal temperature was in the range of the reported optimal temperatures for Streptococcus $\left(37-42^{\circ} \mathrm{C}\right)$ and Lactobacillus $\left(40-45^{\circ} \mathrm{C}\right)$, indicating a possible synergistic effect of proteolytic enzymes of both strains. The response surface methodology used in DOE predicted deproteinization and demineralization values of 92.65 and $97.8 \%$, respectively. The validation experiment on the bioreactor scale showed deproteinization and demineralization levels of 91.45 and $98.4 \%$.

The lactic acid accumulation (Fig. 3a) coincided with the decrease in the protein content (Fig. 3b). Therefore, the rate of protein hydrolysis was linked to the lactic acid production, suggesting a mechanism of acid hydrolysis possibly enhanced by the action of proteases. During the first $20 \mathrm{~h}$ only $7.8 \%$ of the proteins were hydrolysed due to low acid accumulation (Fig. $3 b)$; however, during the exponential phase of LAB growth, almost all proteins were hydrolysed as a result of the increase of lactic acid production. As expected, the time course of demineralization (Fig. 3c) was also coincident with the lactic acid accumulation. Initially, higher extraction levels of minerals and proteins were expected when increasing the substrate mass fraction; however, the experimental results (Table S2) showed that carbon source fractions higher than $10.3 \%$ did not affect the extraction significantly, probably as a consequence of an inhibitory effect on the LAB.

The exponential biomass growth started around $20 \mathrm{~h}$ after inoculation and lasted up to 35-40 h (Fig. 3a). The prolonged lag phase (Fig. 3a) occurred because of the nutrient limitation due to the absence of amino acid supplementation in the medium. Since it was a nitrogen-limited medium, a significant growth was only observed after $20 \mathrm{~h}$, when the availability of nitrogen increased as a result of protein and amino acid hydrolysis (Fig. 3b).

The strain L. plantarum has been widely explored for fermentation of chitinous waste, allowing to reach demineralization and deproteinization values higher than $80 \%(8,33,35,36)$. Additionally, the use of co-cultures of microorganisms has been reported as a feasible alternative to obtain demineralization and deproteinization values higher than $90 \%$ in less time, increasing the efficiency of the process. The reported fermentation times are in the range between 3 and 10 days when only one strain is used $(4,8,33,35,37,38)$ and between 2 and 4 days when extraction with co-cultures is applied $(18,20,36)$. In that case, the use of a mixed culture of $L$. plantarum, L. bulgaricus and $S$. thermophilus was an efficient alternative for biotreatment of shrimp waste, since the extraction values attained in the bioreactor experiments were higher than $90 \%$ and they were achieved in $50 \mathrm{~h}$. The observed rates of deproteinization and demineralization followed second order kinetics with respect to lactic acid molar concentration (Fig. S1). In demineralization reactions, the stoichiometric coefficient for the acid 

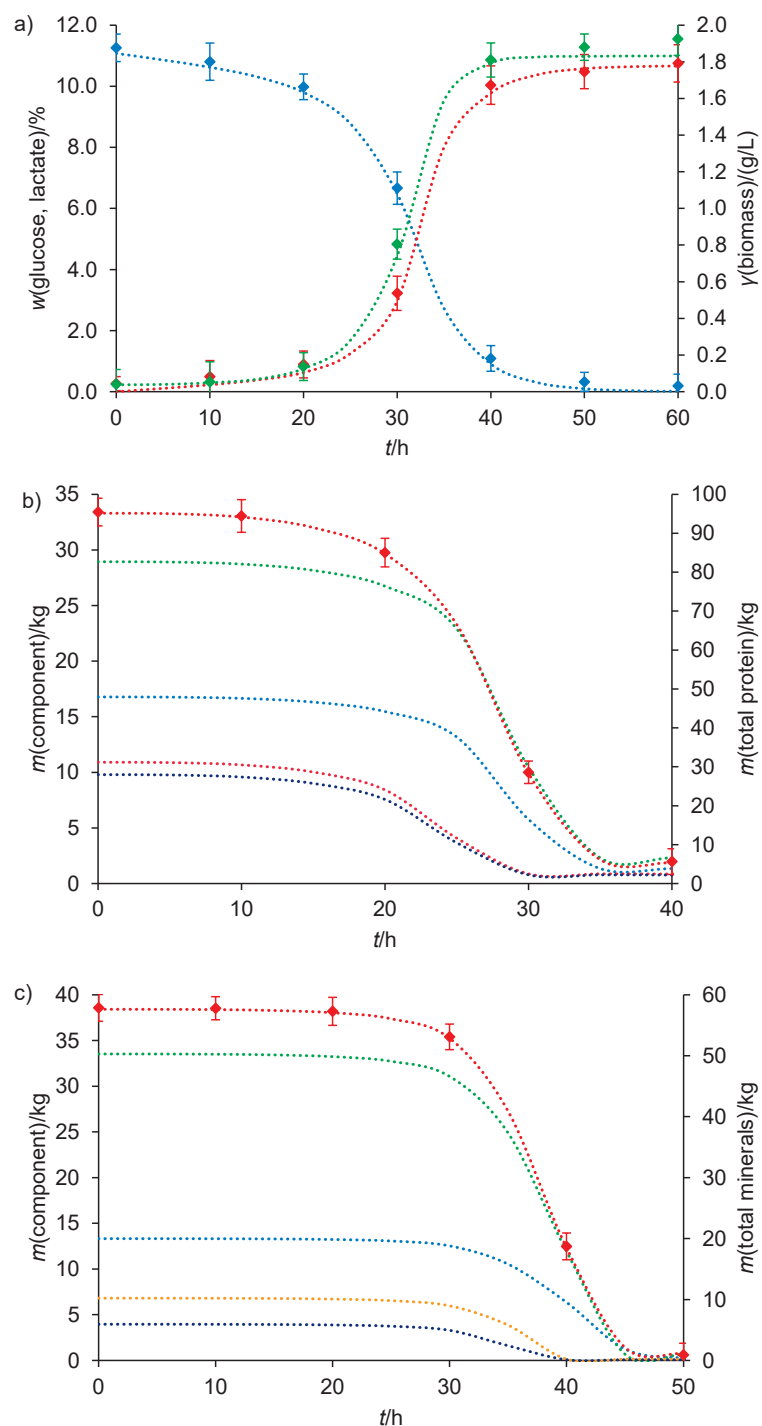

Fig. 3. Simulated (dots) and experimental (diamonds) bioreactor component profiles: a) biomass (green), lactate (red) and glucose (blue) contents, b) total proteins (red), alanine (blue), glutamate (green), phenylalanine (orange) and methionine (dark blue) contents, and c) total minerals (red), calcium carbonate (blue), sodium carbonate (orange), magnesium carbonate (dark blue) and calcium phosphate (green) contents

made it the controlling species. In deproteinization, the second order of reaction is probably a result of the multiple hydrolysis reactions occurring simultaneously on the peptide chains. In both cases, the high activation energy evidences the difficulty of acid species to reach the reactive molecules in the solid matrix, leaving consequently a low reaction rate at low molar concentrations of lactic acid.

Lactate production was considered a pseudo-first order process depending on the substrate molar concentration, assuming a small change in biomass in the sampling interval. For biomass synthesis, the kinetic factor was calculated using the reported activation energy of $43.38 \mathrm{~kJ} / \mathrm{kmol}$ (39). Similarly, the kinetic parameters regarding pigment extraction were calculated from semi-log plot of astaxanthin concentrations shown in Fig. S2 under the same pseudo-first order assumption. The kinetic parameters for glucose uptake, demineralization and deproteinization were calculated from their Arrhenius plot (Fig. S3). Table 3 gives the kinetic parameters and correlation coefficients of regression.

\section{Bioprocess simulation}

The power requirement for the primary crusher was 243.3 W, based on a one-hour cycle for the total grinding of solid load $(248 \mathrm{~kg})$. The 80 th percentile of the particle size distribution of the solids $\left(P_{80}\right)$ was $70 \mathrm{~mm}$ at the inlet and $7.6 \mathrm{~mm}$ at the outlet with a mean size of $4.9 \mathrm{~mm}$. The power required for the secondary size reduction was $348 \mathrm{~W}$ and the $\mathrm{P}_{80}$ at the outlet was $1.7 \mathrm{~mm}$ with a mean of $1 \mathrm{~mm}$, which is appropriate for the dispersion of the solid in the liquid fermentation medium (7).

The simulated time courses of biomass concentration, lactic acid and glucose mass fractions are given in Fig 3a. Similarly, the time courses of proteins and minerals are shown in Figs. $3 \mathrm{~b}$ and $3 c$, respectively. Deviation between simulated time courses and experimental results was assessed by calculating the normalized root mean square (NRMS). The NRMS values for biomass, total protein and mineral contents were 8.7, 6.8 and $5.4 \%$, respectively. NRMS of glucose was 3.4 and of lactic acid $6.2 \%$. The obtained NRMS values indicated an acceptable representation of the experimental data when using the proposed simulation methodology.

The total dry biomass represented $5.56 \%$ of the total substrate mass. The calculated yield of lactic acid from glucose $\left(Y_{\mathrm{ps}}\right)$ was -0.96 ( $m$ (glucose) $/ m$ (lactate) ) and the predicted operational yields of glucose $\left(Y_{\mathrm{sx}}\right)$ and lactic acid $\left(Y_{\mathrm{px}}\right)$ from biomass were -0.033 ( $m$ (biomass) $/ \mathrm{m}$ (glucose)) and 0.032 ( $\mathrm{m}$ (biomass) $/ \mathrm{m}$ (lactate)), respectively. The predicted specific growth rate $\left(\mu_{\max }\right)$ was $0.13 \mathrm{~h}^{-1}$ and the final biomass concentration $1.83 \mathrm{~g} / \mathrm{L}$, which coincided with the experimental data for LAB (40-43).

The simulation of the filtration stage resulted in a cake thickness of $0.052 \mathrm{~m}$ containing $98.4 \%$ of solids after filtration with a drum length of $0.37 \mathrm{~m}$. For drying, the calculated exhaust gas temperature was $117^{\circ} \mathrm{C}$ with a dew point of $97^{\circ} \mathrm{C}$, and the required heat duty was $42.1 \mathrm{~kW}$. Under these conditions, the total mass of chitin was completely dried. The simulated total mass balance per component for the complete process is detailed in Table 4.

The simulation of this bioprocess in Aspen Plus (13) confirmed that one of the main disadvantages of the fermentation of chitin is the long cycle time to complete the extraction; however, this depends on the growth phase of the bacteria. In our experimental design the maximum mineral and protein extraction was achieved in about $50 \mathrm{~h}$. In terms of plant operation, the maximum efficiency of the process was obtained during the exponential phase of growth, coinciding with the higher metabolic activity of bacteria. In the stationary phase, the metabolic activity diminishes considerably; hence, it is not convenient to continue the process at this phase. An alternative might be a chemical post-treatment of the solids to achieve extraction values close to $100 \%$. Since the growth phase of the 
Table 4. Simulation of mass balance per component

\begin{tabular}{|c|c|c|}
\hline Component & $m($ feed $) / \mathrm{kg}$ & $m($ product $) / k g$ \\
\hline Water & 3176.5 & 3201.6 \\
\hline Dextrose & 390 & 0 \\
\hline Methyl palmitate & 16.7 & 16.7 \\
\hline Astaxanthin & 1.1 & 1.1 \\
\hline Calcium carbonate & 13.3 & trace \\
\hline Calcium phosphate & 33.5 & trace \\
\hline Sodium carbonate & 6.8 & trace \\
\hline Magnesium carbonate & 3.9 & trace \\
\hline Alanine peptide & 16.8 & trace \\
\hline Glutamate peptide & 28.9 & trace \\
\hline Phenylalanine peptide & 10.9 & trace \\
\hline Methionine peptide & 9.8 & trace \\
\hline Lysine peptide & 28.7 & trace \\
\hline Biomass & 0.14 & 6.98 \\
\hline$N$-acetyl-D-glucosamine (chitin) & 77.9 & 77.9 \\
\hline Calcium lactate & & 60.9 \\
\hline Sodium lactate & & 8.7 \\
\hline Magnesium lactate & & 9.3 \\
\hline Methionine & & 10.4 \\
\hline Phenylalanine & & 11.5 \\
\hline Alanine & & 1.8 \\
\hline Glutamate & & 30.6 \\
\hline Lysine & & 30.5 \\
\hline Lactic acid & & 309.5 \\
\hline Carbon dioxide & & 14.6 \\
\hline Phosphate & & 22.9 \\
\hline Ammonia & & trace \\
\hline Total mass & 3814.9 & 3814.9 \\
\hline
\end{tabular}

microorganism is a scheduling bottleneck for the production, some authors suggest strategies to overcome this handicap. Possible strategies include re-inoculation of the microorganism every $24 \mathrm{~h}$ for achieving high availability of proteases (33), successive processing with different microorganisms $(18,36)$ or to increase the ratio of inoculum and substrate to reduce the time of processing (44). In terms of process operation and debottlenecking for higher throughput, one alternative might be to consider the reduction of the lag phase by cultivating bacteria adapted to this substrate. In such a case, an initial pre-culture in identical medium, including the solids, must be performed, and once the exponential phase of growth has started, this pre-culture would be used as inoculum. The successive application of this strategy in other microorganisms helped to get evolved populations able to ferment media with high content of solids and reduced the lag phase (45).

\section{Sensitivity of the process to material variability}

Shrimp waste composition varies in protein, mineral and chitin contents approx. $\pm 6 \%$ (by mass), depending on shrimp maturity and nutritional conditions (14). Differences in chemical composition can lead to increments in processing time to achieve the required product quality. In this regard, three different compositions of raw material were tested to check the response of the model to the variability in shrimp waste composition. The original composition (Table 1) was taken as the base-case scenario. The responses of the model regarding the extraction time were used for the determination of total cycle time, energy demand of the process, production cost and gross margin. Simulations demonstrated that the deproteinization was always completed before the demineralization, thus mineral composition is the main factor to consider in the cycle time definition of this batch process. Additionally, the chitin and mineral contents of the shrimp waste influenced the hardness of the material affecting slightly the power input required for the size reduction. The thermal requirements, i.e. energy demand for the reactor, were also calculated as indicators of sensitivity of the model.

For the calculation of production costs, the product price was set to $4.5 \mathrm{USD} / \mathrm{kg}$ chitin, fermentation medium cost to 139.5 USD/cycle, thermal and electric energy costs at 0.017 and 0.059 USD/MJ respectively. As expected, the composition of the raw material influenced the economic performance when chitin was considered as the only valuable product of the process. Nevertheless, the variability of raw material does not hamper significantly the feasibility of the process, whose gross margin ranges at $42-52 \%$. The compositions selected for the three production scenarios and simulation results are summarized in Table 5.

Table 5. Results of production scenarios based on variability of material composition

\begin{tabular}{lcccc} 
& \multicolumn{4}{c}{ w(component)/\% } \\
\cline { 2 - 5 } Component & 5.4 & 6.5 & 8.2 & 7.5 \\
Calcium carbonate & 13.5 & 16.3 & 20.6 & 19.0 \\
Calcium phosphate & 2.7 & 3.3 & 4.2 & 3.9 \\
Sodium carbonate & 1.6 & 1.9 & 2.4 & 2.2 \\
Magnesium carbonate & 0.4 & 0.6 & 0.4 & 0.5 \\
Astaxanthin & 6.7 & 6.7 & 6.7 & 6.7 \\
Methyl palmitate & 6.8 & 5.6 & 4.9 & 5.8 \\
Alanine peptide & 11.7 & 9.6 & 8.5 & 9.9 \\
Glutamate peptide & 4.4 & 3.6 & 3.2 & 3.7 \\
Phenylalanine peptide & 3.9 & 3.3 & 2.9 & 3.4 \\
Methionine peptide & 11.6 & 9.6 & 8.4 & 9.9 \\
Lysine peptide & 31.4 & 33.6 & 29.8 & 28.0 \\
Chitin & & & & \\
Results & 46.2 & 49.5 & 53.6 & 51.3 \\
$t$ (demineralization)/h & 33.9 & 31.7 & 30.6 & 31.3 \\
$t$ (deproteinization)/h & 38.6 & Scenario & Scenario 3 \\
Energy demand/kW & 182.0 & 170.2 & 162 & 174.8 \\
Production cost/(USD/ & 181.5 & 180 & 179 & 180.6 \\
cycle) & & & 335.7 & 314.8 \\
Income/(USD/cycle) & 352.7 & 377.7 & 33.6 \\
Gross margin/\% & 48.53 & 52.33 & 46.68 & 42.62 \\
\hline
\end{tabular}

The economic performance of this process can be substantially improved if the unreacted lactic acid produced during the fermentation is purified and commercialized as part of a biorefinery concept based on lactic acid and associated products (46). Additionally, other valuable byproducts can be obtained during the production of chitin, such as carotenoids and protein hydrolysates (47). 


\section{CONCLUSIONS}

Lactic acid fermentation is a prospective alternative for extraction of chitin with reduced environmental impact, since this kind of process can effectively replace the traditional chemical method of extraction employed currently by the manufacturers. The surface response methodology allowed to identify optimal operating conditions for attaining high levels of demineralization and deproteinization in less than 3 days. The chitin extraction with $\mathrm{LAB}$ co-cultures yields higher extraction values in less time than the processes using solely one strain; however, the operation conditions could be further optimized aiming to decrease the processing time. The integration of experimental data and simulation using Aspen Plus software allowed to represent the process of chitin bioextraction, providing reliable information for further economic and debottlenecking studies, as well as conceptual and detailed plant designs. In this regard, a convenient compound definition and property determinations, along with simplified reaction stoichiometries and experiment-based kinetics allowed to overcome the software limitations for performing this kind of simulations. The presented simulation approach can also be implemented to model other batch bioprocesses taking advantage of the built-in models for reactors, separations and other equipment available in Aspen Plus. The simulations and economic studies showed that chitin bioextraction from shrimp waste is profitable, as indicated by the gross margin between 42 and $52 \%$. In addition to water minimization, equipment and process intensification, the commercialization of valuable sub-products such as pigments, protein hydrolysates and mineral salts must be considered. Additionally, shrimp waste is stable raw material for chitin production and its variability does not hamper significantly the economic performance of the process.

\section{ACKNOWLEDGEMENTS}

This work was partially supported by Administrative Department of Science, Technology and Innovation, COLCIENCIAS, Colombia, Grant No. 111550227815 CTO 674/2011. The authors thank the Research Group of Biotransformation and Research Group in Nutrition and Food Technology of the University of Antioquia, Medellín, Colombia, for providing the native strains of lactic acid bacteria used in this work. The authors also acknowledge the contributions of Prof. Lida Arroyave from the University of Antioquia.

\section{SUPPLEMENTARY MATERIAL}

All supplementary material is available at www.ftb.com.hr.

\section{ORCID IDs}

\author{
D. Gómez-Ríos (i) https://orcid.org/0000-0002-9858-9559 \\ G. Navarro (D) https://orcid.org/0000-0003-3801-0266 \\ P. Monsalve (iD https://orcid.org/0000-0002-8208-8637 \\ R. Barrera-Zapata (D) https://orcid.org/0000-0002-8718-9242 \\ R. Ríos-Estepa (D) https://orcid.org/0000-0002-3287-7056
}

\section{REFERENCES}

1. Pillai CKS, PaulW, Sharma CP. Chitin and chitosan polymers: Chemistry, solubility and fiber formation. Prog Polym Sci. 2009;34(7):641-78.

https://doi.org/10.1016/j.progpolymsci.2009.04.001

2. Zargar V, Asghari M, Dashti A. A review on chitin and chitosan polymers: Structure, chemistry, solubility, derivatives, and applications. ChemBioEng Rev. 2015;2(3):204-26. https://doi.org/10.1002/cben.201400025

3. Kwan TH, Pleissner D, Lau KY, Venus J, Pommeret A, Lin CSK. Techno-economic analysis of a food waste valorization process via microalgae cultivation and co-production of plasticizer, lactic acid and animal feed from algal biomass and food waste. Bioresour Technol. 2015;198:292-9.

https://doi.org/10.1016/j.biortech.2015.09.003

4. Arbia W, Arbia L, Adour L, Amrane A. Chitin extraction from crustacean shells using biological methods - A review. Food Technol Biotechnol. 2013;51(1):12-25.

5. Gómez-Ríos D, Barrera-Zapata R, Ríos-Estepa R. Comparison of process technologies for chitosan production from shrimp shell waste: A techno-economic approach using Aspen Plus ${ }^{\circledR}$. Food Bioprod Process. 2017;103:49-57.

https://doi.org/10.1016/j.fbp.2017.02.010

6. Muxika A, Etxabide A, Uranga J, Guerrero P, de la Caba K. Chitosan as a bioactive polymer: Processing, properties and applications. Int J Biol Macromol. 2017;105(Part 2):1358-68. https://doi.org/10.1016/j.jibiomac.2017.07.087

7. Escobar Sierra DM, Ossa Orozco CP, Quintana Rodríguez MA, Ospina Villa WA. Optimization of a protocol for the extraction of chitin and chitosan from crustacean shells. Sci Tech. 2013;18(1):260-6 (in Spanish). http://doi.org/10.22517/23447214.7555

8. Rao MS, Stevens WF. Fermentation of shrimp biowaste under different salt concentrations with amylolytic and non-amylolytic Lactobacillus strains for chitin production. Food Technol Biotechnol. 2006;44(1):83-7.

9. Petrides D, Carmichael D, Siletti C, Koulouris A. Biopharmaceutical process optimization with simulation and scheduling tools. Bioengineering. 2014;1(4):154-87.

https://doi.org/10.3390/bioengineering1040154

10. Alshekhli O, Foo DCY, Hii CL, Law CL. Process simulation and debottlenecking for an industrial cocoa manufacturing process. Food Bioprod Process. 2011;89(4):528-36. https://doi.org/10.1016/j.fbp.2010.09.013

11. Piccolo C, Bezzo F. A techno-economic comparison between two technologies for bioethanol production from lignocellulose. Biomass Bioenerg. 2009;33(3):478-91.

https://doi.org/10.1016/j.biombioe.2008.08.008

12. Zhang Y, Munir MT, Yu W, Young BR. Modelling batch bioreactions with continuous process simulators. Korean J Chem Eng. 2016;33(12):3343-9.

https://doi.org/10.1007/s11814-016-0244-x 
13. Aspen Plus, v. 8.8, Aspen Technology Inc, Bedford, MA, USA; 2015.

14. Rødde RH, Einbu $A$, Varrum KM. A seasonal study of the chemical composition and chitin quality of shrimp shells obtained from northern shrimp (Pandalus borealis). Carbohydr Polym. 2008;71(3):388-93. https://doi.org/10.1016/j.carbpol.2007.06.006

15. Mæhre HK, Dalheim L, Edvinsen GK, Elvevoll EO, Jensen IJ. Protein determination - Method matters. Foods. 2018;7(1):5. https://doi.org/10.3390/foods7010005

16. Díaz-Rojas El, Argüelles-Monal WM, Higuera-Ciapara I, Hernández J, Lizardi-Mendoza J, Goycoolea FM. Determination of chitin and protein contents during the isolation of chitin from shrimp waste. Macromol Biosci. 2006;6(5):340-7. https://doi.org/10.1002/mabi.200500233

17. Statgraphics Centurion XVII, Statgraphics Technologies Inc, The Plains, VA, USA; 2017. Available from: http://www.statgraphics.com/download-statgraphics-centurion-xvii.

18. Aranday-García R, Román A, Ifuku S, Shirai K. Successive inoculation of Lactobacillus brevis and Rhizopus oligosporus on shrimp wastes for recovery of chitin and added-value products. Process Biochem. 2017;58:17-24.

https://doi.org/10.1016/j.procbio.2017.04.036

19. Arbia W, Arbia L, Adour L, Amrane A, Lounici H, Mameri N. Kinetic study of bio-demineralization and bio-deproteinization of shrimp biowaste for chitin recovery. Alger J Environ Sci Technol. 2017;3(1):29-36.

20. Chakravarty J, Yang CL, Palmer J, Brigham CJ. Chitin extraction from lobster shell waste using microbial culture-based methods. Appl Food Biotechnol. 2018;5(3):141-54.

21. Athimulam A, Kumaresan S, Foo DCY, Sarmidi MR, Aziz RA. Modelling and optimization of Eurycoma longifolia water extract production. Food Bioprod Process. 2006;84(2):139-49. https://doi.org/10.1205/fbp.06004

22. Adeyeye El, O. Adubiaro HO, J. Awodola OJ. Comparability of chemical composition and functional properties of shell and flesh of Penaeus notabilis. Pak J Nutr. 2008;7(6):741-7. https://doi.org/10.3923/pjn.2008.741.747

23. Oliveira AP, Nielsen J, Förster J. Modeling Lactococcus lactis using a genome-scale flux model. BMC Microbiol. 2005;5:39.

https://doi.org/10.1186/1471-2180-5-39

24. Heijnen JJ. Stoichiometry and kinetics of microbial growth from a thermodynamic perspective. In: Ratledge C, Kristiansen B, editors. Basic biotechnology. New York, USA: Cambridge University Press; 2006. pp. 55-72.

25. Makhatadze Gl. Heat capacities of amino acids, peptides and proteins. Biophys Chem. 1998;71(2-3):133-56. https://doi.org/10.1016/S0301-4622(98)00095-7

26. Kashtanov EA, Uryash VF, Kokurina NY, Larina VN. Effect of hydrolysis on heat capacity, thermodynamic functions, and the relaxation transition of crab chitin and chitosan. Russ J
Phys Chem A. 2014;88(2):221-9.

https://doi.org/10.1134/S0036024414020113

27. Dupont C, Chiriac R, Gauthier G, Toche F. Heat capacity measurements of various biomass types and pyrolysis residues. Fuel. 2014;115:644-51.

https://doi.org/10.1016/j.fuel.2013.07.086

28. NIST Chemistry WebBook, SRD69. NIST Standard Reference Database Number 69. Gaithersburg, MD, USA: National Institute of Standards and Technology, U.S. Department of Commerce; 2018.

https://doi.org/10.18434/T4D303

29. Rodriguez F, Ramirez M, Ruiz R, Concha F. Scale-up procedure for industrial cage mills. Int J Miner Process. 2010;97(14):39-43.

https://doi.org/10.1016/j.minpro.2010.07.010

30. Flores-Albino B, Arias L, Gómez J, Castillo A, Gimeno M, Shirai K. Chitin and $L(+)$-lactic acid production from crab (Callinectes bellicosus) wastes by fermentation of Lactobacillus sp. B2 using sugar cane molasses as carbon source. Bioprocess Biosyst Eng. 2012;35(7):1193-200.

https://doi.org/10.1007/s00449-012-0706-4

31. Tarleton ES, Wakeman RJ. Process design for batch separations. In: Solid/liquid separation. Amsterdam, The Netherlands: Elsevier Science; 2007. pp. 256-328. https://doi.org/10.1016/B978-185617421-3/50006-7

32. Moyers C, Baldwin GW. Psychrometry, evaporative cooling and solids drying. In: Green DW, Perry RH, Maloney JO, editors. Perry's chemical engineers' handbook. New York, USA: McGraw Hill; 2008. pp. 1247-51.

33. Neves AC, Zanette C, Grade ST, Schaffer JV, Alves HJ, Arantes MK. Optimization of lactic fermentation for extraction of chitin from freshwater shrimp waste. Acta Sci Technol. 2017;39(2):125-33.

https://doi.org/10.4025/actascitechnol.v39i2.29370

34. Arredondo-Figueroa JL, Pedroza-Islas R, Ponce-Palafox JT, Vernon-Carter EJ. Pigmentation of pacific white shrimp (Litopenaeus vannamei, BOONE 1931) with esterified and saponified carotenoids from red chili (Capsicum annuum) in comparison to astaxanthin. Rev Mex Ing Quím. 2003;2(2):101-8.

35. Rao MS, Stevens WF. Chitin production by Lactobacillus fermentation of shrimp biowaste in a drum reactor and its chemical conversion to chitosan. J Chem Technol Biotechnol. 2005;80(9):1080-7.

https://doi.org/10.1002/jctb.1286

36. Zhang $\mathrm{H}$, Yun S, Song L, Zhang Y, Zhao Y. The preparation and characterization of chitin and chitosan under largescale submerged fermentation level using shrimp by-products as substrate. Int J Biol Macromol. 2017;96:334-9. https://doi.org/10.1016/j.ijbiomac.2016.12.017

37. Duan S, Li L, Zhuang Z, Wu W, Hong S, Zhou J. Improved production of chitin from shrimp waste by fermentation 
with epiphytic lactic acid bacteria. Carbohydr Polym. 2012;89(4):1283-8.

https://doi.org/10.1016/j.carbpol.2012.04.051

38. Ghorbel-Bellaaj O, Hmidet N, Jellouli K, Younes I, Maâlej $\mathrm{H}$, Hachicha R, Nasri M. Shrimp waste fermentation with Pseudomonas aeruginosa A2: Optimization of chitin extraction conditions through Plackett-Burman and response surface methodology approaches. Int J Biol Macromol. 2011;48(4):596-602. https://doi.org/10.1016/j.jjbiomac.2011.01.024

39. Pacheco N, Garnica-González M, Ramírez-Hernández JY, Flores-Albino B, Gimeno M, Bárzana E, Shirai K. Effect of temperature on chitin and astaxanthin recoveries from shrimp waste using lactic acid bacteria. Bioresour Technol. 2009;100(11):2849-54.

https://doi.org/10.1016/j.biortech.2009.01.019

40. Mercier P, Yerushalmi L, Rouleau D, Dochain D. Kinetics of lactic acid fermentation on glucose and corn by Lactobacillus amylophilus. J Chem Technol Biotechnol. 2007;55(2):111-21.

https://doi.org/10.1002/jctb.280550204

41. Burgos-Rubio CN, Okos MR, Wankat PC. Kinetic study of the conversion of different substrates to lactic acid using Lactobacillus bulgaricus. Biotechnol Progr. 2000;16(3):305-14. https://doi.org/10.1021/bp000022p

42. Lin JQ, Lee SM, Koo YM. Modeling and simulation of lactic acid fermentation with inhibition effects of lactic acid and glucose. Biotechnol Bioprocess Eng. 2004;9(1):52-8. https://doi.org/10.1007/BF02949322
43. Trontel A, Barišić V, Slavica A, Šantek B, Novak S. Modelling the effect of different substrates and temperature on the growth and lactic acid production by Lactobacillus amylovorus DSM 20531T in batch process. Food Technol Biotechnol. 2010;48(3):352-61.

44. Sedaghat F, Yousefzadi M, Toiserkani H, Najafipour S. Bioconversion of shrimp waste Penaeus merguiensis using lactic acid fermentation : An alternative procedure for chemical extraction of chitin and chitosan. Int J Biol Macromol. 2017;104(Part A):883-8.

https://doi.org/10.1016/j.jibiomac.2017.06.099

45. Hawkins GM, Doran-Peterson J. A strain of Saccharomyces cerevisiae evolved for fermentation of lignocellulosic biomass displays improved growth and fermentative ability in high solids concentrations and in the presence of inhibitory compounds. Biotechnol Biofuels. 2011;4:49.

https://doi.org/10.1186/1754-6834-4-49

46. Kwan TH, Hu Y, Lin CSK. Techno-economic analysis of a food waste valorisation process for lactic acid, lactide and poly(lactic acid) production. J Clean Prod. 2018;181:72-87. https://doi.org/10.1016/j.jclepro.2018.01.179

47. Cahú TB, Santos SD, Mendes A, Córdula CR, Chavante SF, Carvalho Jr LB, et al. Recovery of protein, chitin, carotenoids and glycosaminoglycans from Pacific white shrimp ( $L i-$ topenaeus vannamei) processing waste. Process Biochem. 2012;47(4):570-7.

https://doi.org/10.1016/j.procbio.2011.12.012 